Review Article

\title{
Influencing Factors of Academic Entrepreneurship-Based Knowledge Mapping: A Comparative Analysis of Chinese and International Literature
}

\author{
Liu Ziyu (iD) and Zhao Lixia \\ School of Economics and Management, Hebei University of Science and Technology, Shijiazhuang, China \\ Correspondence should be addressed to Liu Ziyu; purpleyuliu@163.com
}

Received 5 October 2021; Revised 8 November 2021; Accepted 16 November 2021; Published 29 November 2021

Academic Editor: Daqing Gong

Copyright (c) 2021 Liu Ziyu and Zhao Lixia. This is an open access article distributed under the Creative Commons Attribution License, which permits unrestricted use, distribution, and reproduction in any medium, provided the original work is properly cited.

\begin{abstract}
In order to analyze the hot frontier of academic entrepreneurship and study the influencing factors of academic entrepreneurship, By using citespace V information visualization software and content analysis, 32 papers in CNKI (China National Knowledge Infrastructure) database are retrieved which are indexed by CSSCI (Chinese Social Sciences Citation Index), and 66 papers are retrieved in Web of Science database which are indexed by SSCI (Social Sciences Citation Index); the Chinese and international sample papers were compared and analyzed, and a comparative analysis between Chinese and international papers was made. The results show that the influencing factors of academic entrepreneurship are divided into personal, environmental, and organizational factors. There are many researches on personal factors in China and external factors such as environment, organization, and system in international countries. Chinese research tends to the macrolevel, while international research pays more attention to the microlevel. The research frontier at home and abroad is the research of academic entrepreneurial process at microlevel. Finally, some suggestions are given to academic entrepreneurship: academic exchanges should be strengthened, more support platforms should be set up in university institutions, and the state should introduce incentive policies to enhance the strength and level of academic entrepreneurship.
\end{abstract}

\section{Introduction}

Under the global effect of the era of knowledge economy, China has been actively building a strong country in human resources, implementing the national innovation-driven strategy to strengthen the cultivation of innovative and entrepreneurial talents, and promote economic upgrading and efficiency. In 2014, Premier Keqiang Li proposed the work report of "Mass innovation and entrepreneurship," which once again boosted the national scientific and technological strength and core competitiveness. Universities are regarded as important members of basic research and the main force of technological innovation. The academic entrepreneurship of university teachers, researchers, and academic organizations is not only conducive to the development of the university itself but also a booster to accelerate the construction of an innovative country, industrial upgrading, and transformation as well as the rate of science and technology conversion. There is still no uniform definition of academic entrepreneurship in China and international countries. It can be divided into three categories according to different orientations. First is entrepreneurship-oriented academic entrepreneurship, that is, the entrepreneurial process in which university teachers, researchers, and academic organizations commercialize their academic scientific and technological achievements, emphasizing the commercialization of entrepreneurship [1]. Influenced by business schools, the entrepreneurial thinking is an important source for the emergence of commercialized ideas of faculty and staff [2]. The second is that academicoriented academic entrepreneurship pays attention to the interior of universities and emphasizes the dominant position of academic entrepreneurs [3]. A new viewpoint of "academic enterprise" is put forward in this paper, and the 
influence of universities on entrepreneurial activities is emphasized [4]. The third is the balance between academic and entrepreneurship. Academic research and scientific and technological innovation are conducive to entrepreneurial activities, and the income generated from entrepreneurial activities can help academic activities, which is characterized by knowledge capitalization [5]. It emphasizes that highquality interaction between universities and industries is the key to academic entrepreneurship [6]. As universities gradually step out of the "ivory tower," step into the society and gradually combine with industry, the third concept is widely recognized by scholars.

Academic entrepreneurship research in China and international countries can be divided into three aspects. First, entrepreneurial environment, which is the sum of various factors that academic entrepreneurs and their organizations can use and have to face in the entrepreneurial process. It includes national policies, market and business environment, research and development transfer, culture and social norms, and so on [1]; There are four stages for the evolution of Chinese entrepreneurship policy, although a series of policies have been issued to promote the academic entrepreneurship, but they are not enough to solve the problem of difficult entrepreneurship, so it is necessary to strengthen policy support and top-level design [7]. It is considered that support plan from society and government and relevant policies issued by schools are important environmental factors [8]. Second, individual factor, namely, the personal factor of academic entrepreneurs. Academic entrepreneurship is not only the commercialization process of scientific research achievements but also means the scholars' strategic management for academic career and the creation of new fields [1], such as entrepreneurial ability, psychological factors, gender, entrepreneurial experience, academic strength, and management ability. This paper explores the influence of gender, [9] constructs the evaluation model of university entrepreneurship education teachers' academic entrepreneurial ability, and it is found that teachers' ability of opportunity identification, enterprise management, and academic entrepreneurship are weak [10]. Thirdly, in terms of entrepreneurial practice, there will be many problems in the process of implementing entrepreneurship by academic organizations and individuals, such as role conflict, operation mechanism, and entrepreneurial process analysis [11]. Given the complexity and dynamics of entrepreneurial process, a theoretical model of academic entrepreneurship process including nine key factors is constructed through grounded theory (Fischer, Bruno Brandao). The paper also has studied the impact of university institutions on the degree of academic entrepreneurship [6].

China has issued a series of policies to speed up the construction of world-class subject clusters and increase investment in scientific and technological innovation and academic research. Although some achievements have been made in scientific and technological innovation, the conversion rate of scientific research results in universities is not high, and most of them are ended in the form of papers and reports. Due to the fear that universities will become market vassals, only some universities have liberalized their management and control, and policies have not been fully implemented. There are many factors influencing academic entrepreneurship of university teachers. The main factors are external environmental factors such as entrepreneurial policy, entrepreneurial education, economy, and society. Among internal personal factors, the key factors are opportunity recognition ability, risk perception ability, and self-efficacy. The research on influencing factors in Chinese literature is divided into theoretical level, model construction and empirical analysis; Yangjie Huang summarizes the influencing factors of academic entrepreneurship through the analysis of Chinese and international literature [3]. Based on the planning theory, grounded theory, and structural equation, the paper makes model building and empirical analysis on the influencing factors of academic entrepreneurship of university teachers, which can be roughly divided into personal factors, environmental factors, and organizational factors $[12,13]$. Through the analysis and comparison of 66 international articles, it is concluded that the determinants of academic entrepreneurship success can be divided into external factors and personal factors. The external factors include support plans from society and government and related policies issued by schools [8]. The personal factors include gender, entrepreneurial ability, experience, and creativity and psychological factors.

Many scholars are using Citespace for literature and visual analysis. Tanriverdi $\mathrm{G}$ et al. deployed a comprehensive bibliometric analysis and graphical mapping of the JATM knowledge body through Citespace visualization of 1483 JATM papers from 2001 to 2019 [14]. Chen, Xiaoyan et al. aimed to identify the research status quo and development trends of HSR using visualization analysis with citespace [15]. Sheikhnejad, Yahya et al. undertook a comprehensive scientometric analysis to visualize and quantitatively measure the outcome of the scientific enterprise to construct sustainable urban and rural areas through Citespace [16]. Huang, Li et al. made scientific quantitative analysis on 747 academic papers related to climate change and carbon sequestration published during 1991-2018, aiming to describe the knowledge landscape by identifying and revealing the basic characteristics, research strength, knowledge base, research topic evolution, and research hot spots in this field [17]. To sum up, Citespace can be used for literature measurement and analysis.

This study focuses on the hot frontier analysis and influencing factors of academic entrepreneurship. With the title of "academic entrepreneurship," 32 Chinese literatures were retrieved in CSSCI database under CNKI and 66 literature from international countries in SSCI database on Web of Science, and this paper conducted analysis for literature. The influencing factors of academic entrepreneurship are summarized as personal factors, entrepreneurship education, entrepreneurial policies and organizational factors, and so on. We define environmental factors and organizational factors as external influencing factors. In the meanwhile, literature analysis and information visualization are used to conduct a panoramic display analysis of academic entrepreneurship, with the hope of providing a reference for academic entrepreneurship research. 
Through literature analysis, there are, respectively, two review literatures from China and international countries on academic entrepreneurship in the sample literature. The review literature on the three factors affecting individuals, environment, and organization has not been found yet. Therefore, with the purpose of applying Citespace and content analysis to this field of knowledge, this paper analyzes the academic entrepreneurship articles published in CSSCI during the period of 13 years (2008-2020) and the sample literature from 2000 to 2020 on the core collection of Web of Science, so as to make up for the lack of research:

This article is divided into four parts. Section 1 introduces academic entrepreneurship and influencing factors. Section 2 introduces the methods and techniques used in this article. In this paper, the results of the analysis are in Section 3. Finally, Section 4 summarizes the research results and explains the limitations of this research and the suggestions for future research.

\section{Methods}

The research route of this paper is shown in Figure 1.

2.1. Literature Selection. Chinese literature is retrieved in the CSSCI, using advanced retrieval methods, and the retrieved article is titled "Academic Entrepreneurship." The time range is unlimited, and the test data year is 2008-2020; a total of 32 data samples are obtained after screening the data.

The international literature is searched in the core collection of Web of Science, and the SSCI library is selected for the search. The search method is title= ("academic entrepreneurship"). The document type is a journal; the time range is all years; after retrieval, the document year is 2000-2020, a total of 86 documents; 20 irrelevant documents are manually screened out, a total of 66 sample documents.

2.2. Literature Processing. This research adopts the $\mathrm{R} 1$ version of Citespace V 5.0, which is a type of information visualization software, it can be used to measure a specific Chinese literature (set) and draw a knowledge map of multivariate, time sharing, and dynamic knowledge. The evolution process of a knowledge field is concentrated on a citation network map to analyze the potential dynamic mechanism of discipline evolution and explore the frontier of discipline development [18].

Firstly, the txt text is exported from the database, then the txt text is imported into Citespace software, and the knowledge map of cooperation between authors and institutions, co-cited documents, co-occurrence of keywords, mutation words, and so on is generated by Citespace. Finally, through the knowledge map, the research on academic entrepreneurship at home and abroad is fully displayed, and its hotspots and development trends are sorted out.

Content analysis is a quantitative and qualitative research method, which makes the quantification of text data system meaningful.
2.3. Result Analysis. The article mainly analyzes the results from the following six aspects:

(1) Document distribution analysis: understand the development of disciplines through literature distribution

(2) Cooperative network analysis: through analysis chart of author cooperation, institutional cooperation, and national cooperation understand the situation and differences of academic entrepreneurship cooperation between China and international countries

(3) Literature cocitation analysis: core articles that influence international literature

(4) Research hotspots analysis: through keyword cooccurrence and cluster analysis, the current research hot spots are analyzed

(5) Frontier analysis: research frontier through the analysis of abrupt word graph

(6) Content analysis: analyze the documents through content analysis to make up for the shortage of software analysis documents

\section{Result Analysis}

This section analyzes 32 Chinese sample documents published on CSSCI during the 12 years from 2008 to 2020 and 66 international countries sample documents in the Web of Science database during the 20 years from 2000 to 2020 and obtains the results of data visualization analysis.

3.1. Document Distribution. The distribution of the number of publications can also show the development of disciplines. As shown in Figure 2, the Chinese academic entrepreneurship was in a period of theoretical research accumulation from 2008 to 2012. In 2010, China issued a university entrepreneurship policy to support academic entrepreneurship. From 2012 to 2015, academic entrepreneurship research was in a rapid development stage, with a wide range of research directions. In 2016, the national innovation-driven strategy was also one of the reasons for the growth of academic entrepreneurship literature. The research on academic entrepreneurship in international countries is very early. From 2000 to 2010, there were not many documents on SSCI. Most of the papers focus on the basic research on academic entrepreneurship, such as summary and theoretical research on academic entrepreneurship, academic entrepreneurship development, and academic entrepreneurship influencing factors. The overall trend of international literature is on the rise. Compared with the trend of international literature research, the Chinese paper policy orientation is stronger and international research is more active.

\subsection{Author Cooperation, Institutional Cooperation, and National Cooperation}

3.2.1. The Cooperation Network for Chinese Author and Important Authors. There are a total of 46 nodes and 45 connections for the knowledge graph generated by the 


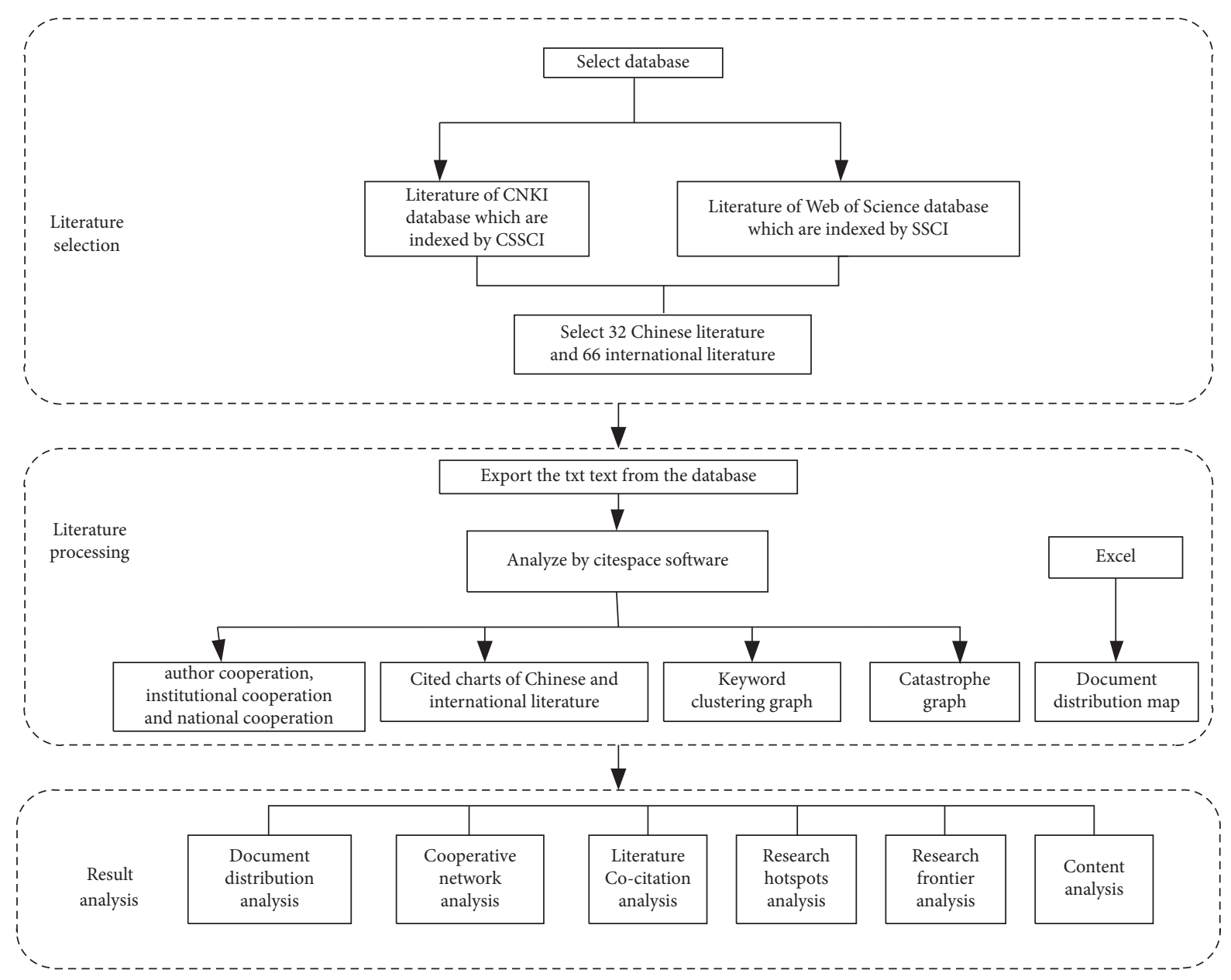

FIgURe 1: Research route chart.

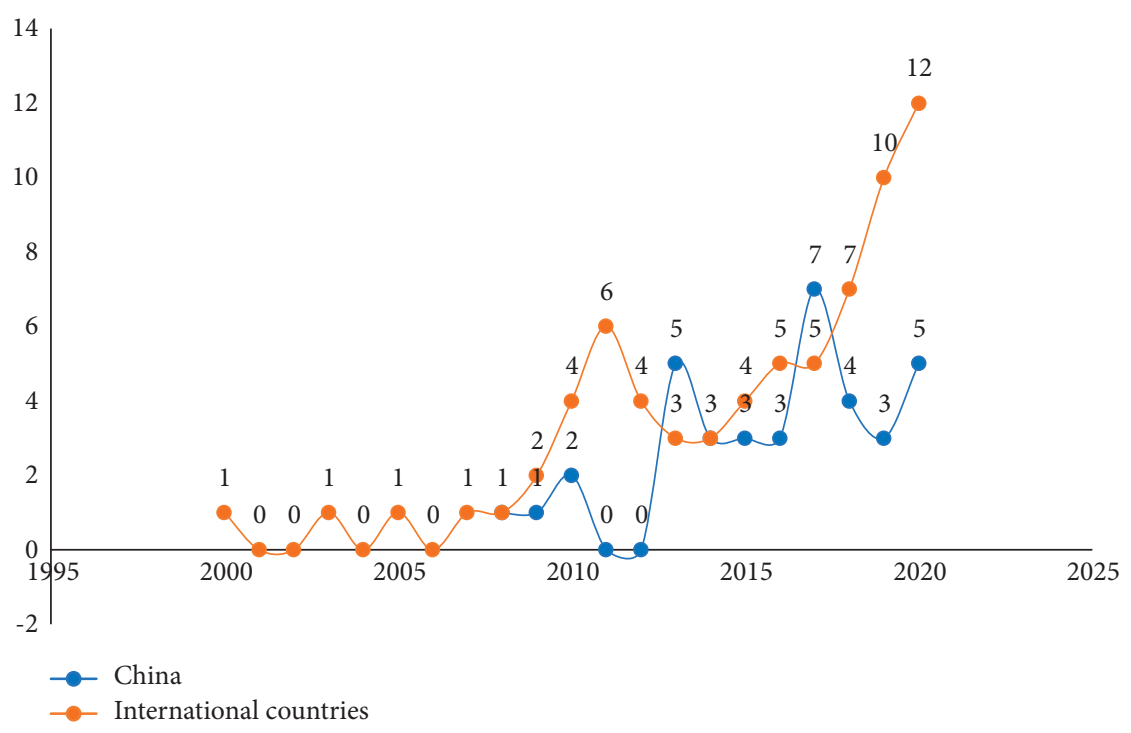

FIGURE 2: Distribution map of postvolume.

software, indicating that there are 46 researchers and a total of 45 collaboration items of authors. It can see been from the figure that academic entrepreneurship research is closely connected, forming a larger research cooperation group, including Huajing Li, Gang Wang and Xiaodong Xing, Yangjie Huang, Xiaodong Zou and Ping Hou, Zhaohui Yin and Ruijun Li, and other people. As shown in Table 1, according to the formula $m=0.749\left(n_{\max }\right) 0.5$ in price law, it 
TABLE 1: Temperature and wildlife count in the three areas covered by the study.

\begin{tabular}{lcc}
\hline Serial number & Volume & Author \\
\hline 1 & 5 & Huajing Li \\
2 & 4 & Yangjie Huang \\
3 & 3 & Xiaodong Zou \\
4 & 3 & Ruijun Li \\
5 & 3 & Zhaohui Yin \\
6 & 2 & Wenhua Zhao \\
7 & 2 & Yang Su \\
8 & 2 & Mei Ren \\
9 & 2 & Ping Hou \\
10 & 2 & Gaofeng Yi \\
\hline
\end{tabular}

gives $m=2$. Therefore, the authors with 2 or more articles are important authors in China. Huajing Li has published a total of 5 articles and has carried out many researches on higher education, macroeconomic management, and sustainable development. In terms of the amount of published articles, Yangjie Huang ranks the second. He has in-depth research on higher education, enterprise economy, and other aspects.

3.2.2. The Cooperation Network for International Authors and Important Authors. As shown in Figure 3, $N=147$ and $E=204$ in the atlas. There are a total of 147 researchers in international literature and 204 cooperation items among researchers. Most of the collaborations among the authors are small groups, and only two large groups have been formed and have a large number of papers. 4 of which were published by Wright Mike, Siegel Donald S, etc., who conducted many researches on academic entrepreneurship and academic entrepreneurship in business schools. Abreu Maria and Grinevich Vadim published 3 papers; they have many studies on the academic entrepreneurial process, humanities and creative arts; other papers for small groups and individuals are published in two articles, such as Wood Matthew S personal research; Czarnitzki Dirk, and Toole Anderw A. The authors with two or more papers calculated by Price Law are important ones. The statistics are shown in Table 2.

There is no obvious difference between authors' cooperation in China and international countries. Most of them are small-group cooperation with average output. There are more productive authors in China while more other authors choose to cooperate with each international. Therefore, Chinese research should strengthen academic exchange and experience sharing and accelerate the transformation of academic and scientific achievements.

3.2.3. Cooperation Network of Chinese Institutions. In the Chinese institution knowledge map, $N=21$ and $E=2$; there are 21 institutions in the institution cooperation network, and there are only 2 cooperation items. The cooperation between institutions is not close, and most of them are independent research. The main research institutions are Beijing Forestry University, Wuhan University, Tianjin Polytechnic University, and Shanghai Jiaotong University; research is mainly based on university research. The amount of documents issued by each agency is shown in Table 3.

3.2.4. The Cooperation Network of International Institutions. As shown in Figure 4, $N=99$ and $E=87$ in the cooperation map of international institutions. Universities are more in international research institutions. There are 99 research institutions and 87 cooperation projects. The cooperation among institutions is close. Among the international research institutions, there are many research institutions in the United States, Canada, and European countries and international countries, and cross-school and cross-regional research is more frequent. See Table 4 for the publication volume of specific institutions. In China, most Chinese research is carried out by independent institutions, which do not have close cooperation with each other. Therefore, academic entrepreneurship research should not be conservative, and schools should open policies to encourage academic entrepreneurship exchanges.

3.2.5. National Cooperative Network. As shown in Figure 5, through software, we find that $N=27$ and $E=22$ in 66 literature, that is, there are total 27 countries with 22 items of cooperation. The specific publication volume is shown in Table 5, of which USA has 20 articles at most and the centrality 0.26 ranks the 3rd; England has 10 articles and the centrality 0.15 ranks the 4 th; Germany has 8 papers and the centrality 0.28 ranks the 2nd; Belgium has 7 papers and the centrality 0.39 ranks the 1 st; China ranks 5 th in publication volume with the centrality of 0.01 . The centrality represents the importance of the node in the network. Based on the amount of papers published and the centrality, it is found that the United States, Belgium, Germany, and the United Kingdom are the main researchers, and there is a lot of cooperation among these countries. China's academic entrepreneurship research is not at the advanced level in the world. It needs to further strengthen international cooperation and exchange, so as to improve the strength of Chinese academic entrepreneurship research.

\subsection{Literature Cocitation}

3.3.1. Cocitation of Chinese Literature. The software is used to generate the knowledge map of Chinese literature cocited. In the map, $N=256$ and $E=792$, indicating that there are 256 references and 792 lines in 32 documents. It shows the frequency of two different references appearing in the same paper. As indicated in Table 6, there are a total of 6 highly cited documents. Through the analysis of the documents, it is found that Chinese research focuses on theoretical basic research, such as the theoretical research on the concept, connotation, mode and problems of research universities, academic entrepreneurship, and academic entrepreneurs.

3.3.2. Cocitation of International Literature. It generates a document cocitation map through the software Citespace (as shown in Figure 6), among which 66 documents have 


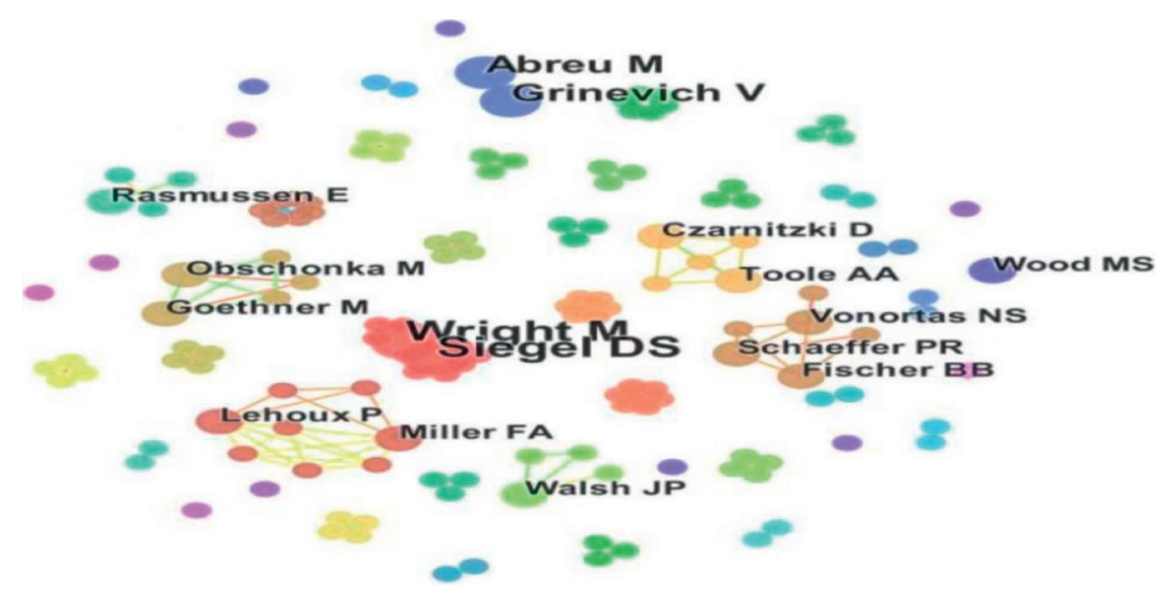

FIGURE 3: International authors' cooperation network.

TABLE 2: Important international authors.

\begin{tabular}{lcc}
\hline Serial number & Volume & Author \\
\hline 1 & 4 & Wright Mike \\
2 & 4 & Siegel Donald S \\
3 & 3 & Abreu Maria \\
4 & 3 & Grinevich Vadim \\
5 & 2 & Lehoux Pascale \\
6 & 2 & Wood Matthew s \\
7 & 2 & Toole Anderw A \\
8 & 2 & Rasmussen Einar \\
9 & 2 & Obschonka Martin \\
10 & 2 & Vonortas Nicolas S \\
11 & 2 & Miller Fiona A \\
12 & 2 & Schaeffer Paola Rucker \\
13 & 2 & Fischer Bruno Brandao \\
14 & 2 & Czarnitzki Dirk \\
15 & 2 & Walsh JohnvP \\
16 & 2 & Goethner Maximilian \\
\hline
\end{tabular}

TABle 3: Number of documents issued by Chinese institutions.

\begin{tabular}{|c|c|c|c|}
\hline Serial number & Mechanism & Volume & Years \\
\hline 1 & Beijing Forestry University. Economics and Management & 4 & 2009 \\
\hline 2 & Wuhan University. Institute of Educational Science & 4 & 2017 \\
\hline 3 & Tianjin Polytechnic University & 3 & 2014 \\
\hline 4 & Shanghai Jiaotong University & 2 & 2017 \\
\hline 5 & Zhejiang University of Technology Management & 2 & 2019 \\
\hline 6 & Tianjin Polytechnic University & 2 & 2014 \\
\hline 7 & Tianjin University of Commerce & 2 & 2014 \\
\hline
\end{tabular}

references $N=563$, a total of 563 articles, and $E=1868$. There are many times for two different documents appear in the same paper, and the high cited documents are shown in Table 7 in detail. The ranking order is the order of citation frequency in 66 documents, and the frequency statistics is the total number of citations on Web of Science. In the highly cited literature, Rosa Grimaldi conducted a systematic assessment for academic entrepreneurship and discussed academic entrepreneurship at the level of individuals, organizations, and institutions [19]; Maria Abreu defined entrepreneurial activities and proposed that academic and academic entrepreneurship literature cannot only focus on patent-related entrepreneurial activities [20]. Through observing the background and working environment of a large number of faculty and staff, Janet Bercovitz studied the change process of individuals participating in organizational planning for technology transfer activities [21]. Toby E. Stuart studied the influence of intimate relationships among colleagues in the business field on the transition of life scientists to entrepreneurs [22]. Pabold'este Markus perkmann mainly promotes research in the cooperation between scholars and industries in entrepreneurial universities, rather than driven by commercialization like patents and derivative companies 


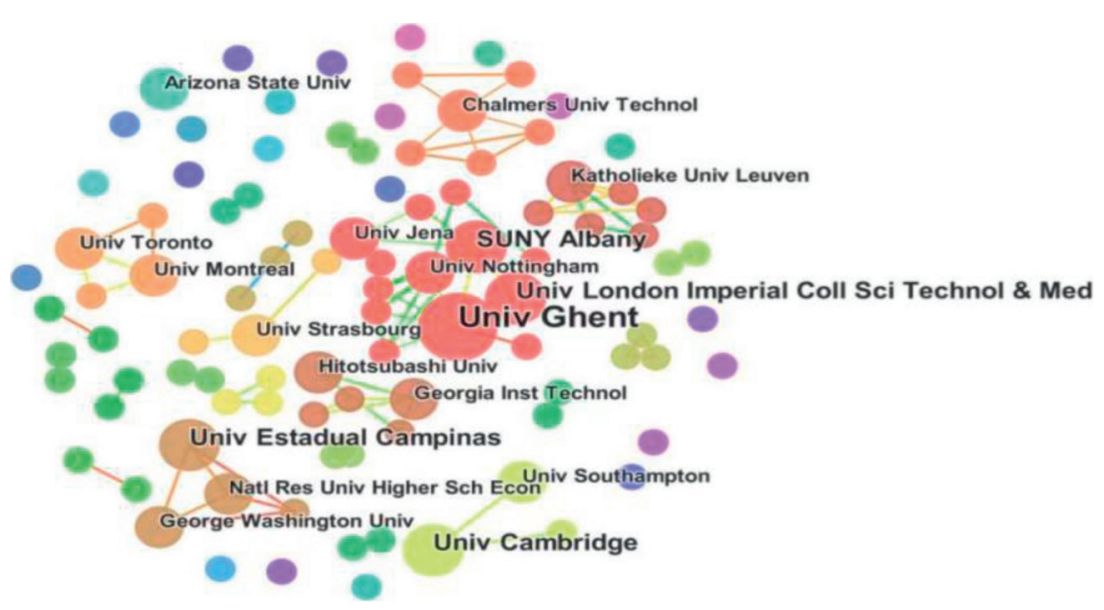

FIGURE 4: Cooperation network of international institutions.

TABLE 4: Document issued by international institutions.

\begin{tabular}{|c|c|c|c|}
\hline Serial number & Mechanism & Volume & Years \\
\hline 1 & Univ Ghent & 5 & 2011 \\
\hline 2 & Univ London Imperial Coll Sci Technol and Med & 3 & 2011 \\
\hline 3 & SUNY Albany & 3 & 2011 \\
\hline 4 & Univ Estadual Campinas & 3 & 2018 \\
\hline 5 & Univ Cambridge & 3 & 2013 \\
\hline 6 & Univ Montreal & 2 & 2015 \\
\hline 7 & Georgia Inst Technol & 2 & 2012 \\
\hline 8 & Arizona State Univ & 2 & 2018 \\
\hline 9 & Univ Strasbourg & 2 & 2015 \\
\hline 10 & Chalmers Univ Technol & 2 & 2018 \\
\hline 11 & Univ Southampton & 2 & 2014 \\
\hline 12 & Univ Toronto & 2 & 2015 \\
\hline 13 & Natl Res Univ Higher Sch Econ & 2 & 2018 \\
\hline 14 & George Washington Univ & 2 & 2018 \\
\hline 15 & Univ Jena & 2 & 2012 \\
\hline 16 & Univ Nottingham & 2 & 2009 \\
\hline 17 & Katholieke Univ Leuven & 2 & 2010 \\
\hline 18 & Hitotsubashi Univ & 2 & 2012 \\
\hline
\end{tabular}

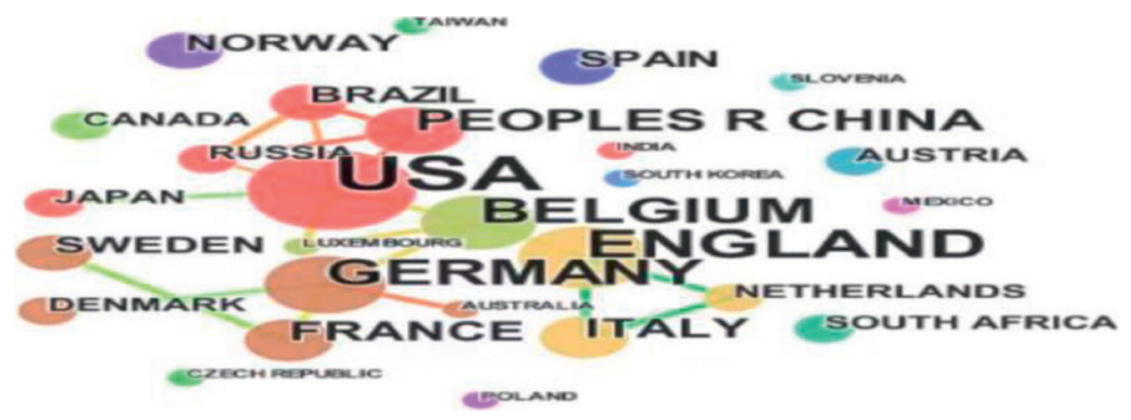

Figure 5: National cooperation network.

[23]. Markus Perkmanna summarized academic participation and studied the differences between academic participation and commercialization [24]. Carolin Haeussler commented on the personal attributes, social resources, material, value, and reputation of more than 2000 life scientists in Germany and the UK participating in commercial activities. It is found that different scientists have different opinions on the value of patents. Some think that academic and business can go hand in hand, while some think that reputation is more important [25]. Frank. T. Rothaermel comprehensively analyzed the early research articles on academic entrepreneurship in the United States and Europe and summarized four research streams [26].

Among the Chinese and international cocited documents, the Chinese cocited documents tend to focus on theoretical research at the macrolevel, while international 
TABLE 5: National publication volume.

\begin{tabular}{lccc}
\hline Serial number & Country & Volume & Centrality \\
\hline 1 & USA & 20 & 0.26 \\
2 & England & 10 & 0.15 \\
3 & Germany & 8 & 0.28 \\
4 & Belgium & 7 & 0.39 \\
5 & Peoples Republic China & 5 & 0.01 \\
6 & France & 4 & 0.08 \\
7 & Italy & 4 & 0.00 \\
8 & Spain & 3 & 0.00 \\
9 & Sweden & 3 & 0.00 \\
10 & Norway & 3 & 0.00 \\
11 & Brazil & 3 & 0.00 \\
\hline
\end{tabular}

TABLE 6: Highly cited documents in China.

\begin{tabular}{|c|c|c|c|}
\hline $\begin{array}{l}\text { Serial } \\
\text { number }\end{array}$ & Highly cited literature & $\begin{array}{c}\text { Cited } \\
\text { frequency }\end{array}$ & Author \\
\hline 1 & $\begin{array}{c}\text { Entrepreneurial University: Connotation, Organization and Practice } \\
\text { Approaches }\end{array}$ & 81 & $\begin{array}{l}\text { Xiaodong Zou, Hancong } \\
\text { Chen }\end{array}$ \\
\hline 2 & $\begin{array}{l}\text { A Study on Academic Entrepreneurship Based on the Perspective of } \\
\text { Knowledge Spillover }\end{array}$ & 43 & Huajing Li, Gang Wang \\
\hline 3 & $\begin{array}{c}\text { Scholar, Academic Organization and Environment: A Review of the Research } \\
\text { on Academic Entrepreneurship }\end{array}$ & 37 & Huajing Li \\
\hline 4 & $\begin{array}{l}\text { A Study on Role Identity Evolution Patterns of Scholars in the Background of } \\
\text { Academic Entrepreneurship }\end{array}$ & 34 & $\begin{array}{l}\text { Youli Huang, Ting Xue, } \\
\text { Hong Zhou }\end{array}$ \\
\hline 5 & $\begin{array}{c}\text { The Process of Sense-Making of Transformation from University Researchers } \\
\text { to Entrepreneurs on Multi-Case Study }\end{array}$ & 32 & Fei Yao \\
\hline 6 & $\begin{array}{c}\text { New trends in Academic entrepreneurship research: Concept, Characteristics } \\
\text { and Factors }\end{array}$ & 20 & $\begin{array}{l}\text { Yangjie Huang, Xiaodong } \\
\text { Zou, Ping Hou }\end{array}$ \\
\hline
\end{tabular}

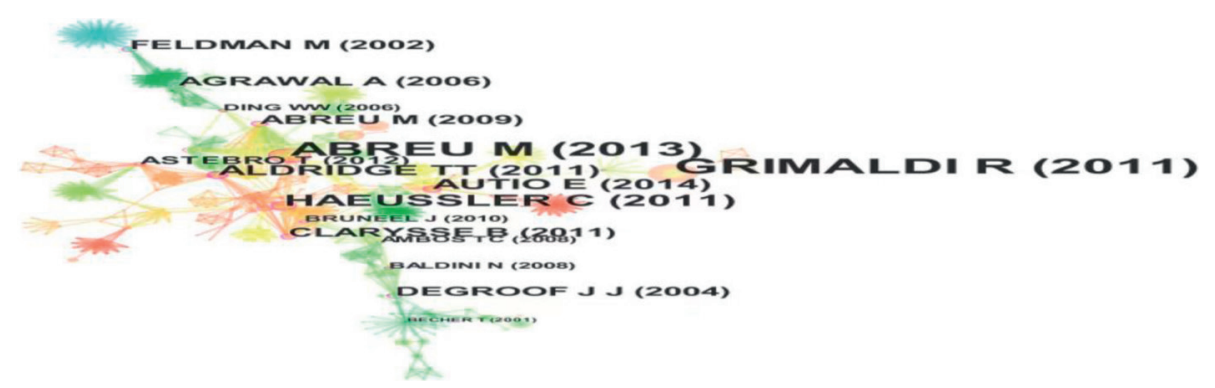

FIGURE 6: Cocited international documents.

scholars pay more attention to the influence of individuals, institutions, and organizations on academic entrepreneurship at microlevel and the process of academic entrepreneurship through empirical research.

\subsection{Research Hotspots}

3.4.1. Chinese Research Hotspots. As shown in Table 8, we import 32 documents into the software to count the frequency and centrality of high-frequency keywords. Combining the frequency and centrality, we can see that Chinese research enthusiasm for academic entrepreneurship, research (entrepreneurial) universities, entrepreneurship education, entrepreneurship policy, role conflict, and academic entrepreneurship is very high. By clustering keywords, the Atlas is generated, in which $(Q$ value $)=$
$0.749>0.3$, the clustering structure is significantly close to 1 , and $(S$ value $)=0.9782>0.7$, indicating that the clustering efficiency is high. By software analysis, the keywords are divided into 10 categories (academic entrepreneurship, entrepreneurship education, research university, discipline organization, grounded theory, entrepreneurship policy and knowledge, etc.), as shown in Table 9. (Yin Zhaohui, Li Ruijun) Through the research and analysis of American research universities, this paper gives suggestions on academic entrepreneurship of Chinese university teachers, such as policies, platforms, and reform assessment mechanisms [27]. By taking international academic entrepreneurship schools as an example, it is demonstrated that entrepreneurship education is conducive to academic entrepreneurship and talent training in universities [28]. Through an empirical study of universities in 31 provinces, it is found that academic entrepreneurship and regional 
TABLE 7: Highly cited documents in international countries.

\begin{tabular}{|c|c|c|c|}
\hline $\begin{array}{l}\text { Serial } \\
\text { number }\end{array}$ & Highly cited literature & $\begin{array}{c}\text { Cited } \\
\text { frequency }\end{array}$ & Author \\
\hline 1 & 30 years after Bayh-Dole: Reasessing academic entrepreneurship & 344 & Rosa Grimaldi \\
\hline 2 & $\begin{array}{c}\text { The nature of academic entrepreneurship in the UK: Widening the focus on } \\
\text { entrepreneurial activities }\end{array}$ & 144 & Maria Abreu \\
\hline 3 & Academic Entrepreneurs: Organizational Change at the Individual Level & 378 & Janet Bercovitz \\
\hline 4 & $\begin{array}{l}\text { When Do Scientists Become Entrepreneurs? The Social Structural Antecedents of } \\
\text { Commercial Activity in the Academic Life Sciences1 }\end{array}$ & 329 & Toby E. Stuart \\
\hline 5 & $\begin{array}{c}\text { Why do academics engage with industry? The entrepreneurial university and } \\
\text { individual motivations }\end{array}$ & 353 & $\begin{array}{l}\text { PabloD'Este • Markus } \\
\text { Perkmann }\end{array}$ \\
\hline 6 & $\begin{array}{c}\text { Academic engagement and commercialization: A review of the literature on } \\
\text { university-industry relations }\end{array}$ & 740 & Markus Perkmanna \\
\hline 7 & $\begin{array}{c}\text { Breaking the Ivory Tower: Academic Entrepreneurship in the Life Sciences in UK } \\
\text { and Germany }\end{array}$ & 128 & Carolin Haeussler \\
\hline 8 & University entrepreneurship: a taxonomy of the literature & 689 & Frank.T.Rothaermel \\
\hline 9 & Academic Entrepreneurship: Time for a Rethink? & 157 & $\begin{array}{l}\text { DonaldS.Siegel and Mike } \\
\text { Wright1 }\end{array}$ \\
\hline
\end{tabular}

TABLE 8: Keyword frequency table.

\begin{tabular}{lccc}
\hline Serial number & Keyword name & Frequency & Centrality \\
\hline 1 & Academic entrepreneurship & 23 & 0.94 \\
2 & Research university & 3 & 0.13 \\
3 & Entrepreneurial university & 3 & 0.17 \\
4 & Discipline organization & 2 & 0.02 \\
5 & Rooted theory & 2 & 0.10 \\
6 & Entrepreneurship education & 2 & 0.09 \\
7 & Academic entrepreneurship & 2 & 0.02 \\
8 & Grounded analysis & 2 & 0.00 \\
9 & Role conflict & 2 & 0.05 \\
10 & Theory of planned behavior & 2 & 0.01 \\
11 & Teachers in research universities & 1 & 0.01 \\
12 & Academic entrepreneurship policy & 1 & 0.00 \\
13 & Scholar entrepreneurship & 1 & 0.00 \\
14 & Citespace & 1 & 0.00 \\
15 & Academic ecology & 1 & 0.00 \\
16 & Influence factor & 0.00 \\
\hline
\end{tabular}

TABLE 9: Cluster member table.

\begin{tabular}{lcccc}
\hline Category & Category name & Category members & $S$ value \\
\hline 0 & Academic entrepreneurship & Academic entrepreneurship; university; Stanford University & 0.952 \\
1 & Entrepreneurship education & Entrepreneurship education; team management; university entrepreneurial & 0.945 \\
2 & Research university & center & 0.959 \\
3 & Discipline organization & Discipline organization; Organizational performance; academic & 0.968 \\
4 & Rooted theory & Rooted theory; influencing factors; theory of planned behavior & 0.967 \\
5 & Scientific research institutions & Scientific research institutions; binary ability; dynamic management model & 1 \\
6 & University academic & University academic entrepreneurship; regional economy; coupling & 1 \\
7 & entrepreneurship & Academic entrepreneurship policy; coword analysis; colleges and universities & 1 \\
8 & Universities serve the society & Universities serve the society; research hotspots; academic entrepreneurship & research &
\end{tabular}

economy are coupled, giving play to their own characteristics and improving the ability to serve the society [5]. Comprehensive map analysis and literature analysis show that the research focus of academic entrepreneurship has risen from basic theoretical research such as concept, connotation, current situation, and development trend to internal, external, subject, and motivation research such as entrepreneurial process, role conflict, performance, influencing factors and entrepreneurial power, and recent empirical research. 
3.4.2. International Research Hotspots. As shown in Table 10, we imported 66 documents into the software to count the frequency and centrality of high-frequency keywords. Combining frequency and centrality, we can see that there are many researches on academic entrepreneurship, technology transfer, university, knowledge, industry, commercialization, innovation, and scientist in international countries. Representative hot words can be obtained by keyword clustering. As shown in Figure 7, 11 categories are generated by keyword clustering. In the figure, $Q$ value $=0.6929>0.3$, the clustering structure is significantly close to 1 , and $S$ value $=0.6663>0.6$, indicating that the clustering efficiency is up to standard. The 11 categories are intention, comparative research, gender difference, biomedical research, biotechnology, start up, personality (see Table 11) for bioenergy, firm, scientific productivity, modus operandi, and perspectives at different organizational levels.

According to the analysis of 66 documents and knowledge map data, the research on university organization is a hot spot (Fischer, Bruno Brandao, Michael C, etc.). has made a theoretical and empirical analysis on the influence of university openness and operational logic on academic entrepreneurial activities. Strengthening highquality links between universities and companies is helpful for scholars to participate in entrepreneurial activities $[4,6]$. Another hot spot studies biotechnology, digital technology and academic entrepreneurship in different industries and directions (Pierpaigi Rippa; Gosens, Jorrit), respectively, analyzed the commercialization, innovation, and limitations of biotechnology and digital technology [29, 30]. Another hot spot is the personal research of scientists and scholars (Abreu, Maria) analyzed a large number of British scholars' data and found that men and women have different emphasis on academic entrepreneurship, and women prefer applied research and junior positions [20]; Kalar, Barbara, 2020) made a research on entrepreneurial ability and put forward the importance of self-efficacy [31].

From the research hotspots in Chinese and international countries, we can see that the Chinese hotspots focus on the obstacles to academic entrepreneurship in colleges and universities and the research on the transformation of researchers themselves. The difference between international literature and Chinese hot research is that more microscopic factors in the process of academic entrepreneurship are often empirically analyzed through models and analytical frameworks.

\subsection{Frontier Analysis}

3.5.1. Chinese Frontier Analysis. Through the analysis of emergent words in 32 documents, we can predict the frontier research hotspots in a certain period of time. The period of 2008-2009 is the theoretical accumulation period of academic entrepreneurship, and most of the documents have no emergent keywords. During 2010-2012, there was a wave of academic entrepreneurship in China, and a large number of keywords began to appear in papers. Knowledge spillovers, research universities, academic ecology, and system
TABLE 10: Keyword frequency table.

\begin{tabular}{lccc}
\hline $\begin{array}{l}\text { Serial } \\
\text { number }\end{array}$ & Keyword name & Frequency & Centrality \\
\hline 1 & Academic & 38 & 0.06 \\
2 & entrepreneurship & 25 & 0.06 \\
3 & Technology transfer & 18 & 0.02 \\
4 & University & 18 & 0.08 \\
5 & Performance & 17 & 0.06 \\
6 & Knowledge & 17 & 0.13 \\
7 & Science & 15 & 0.14 \\
8 & Innovation & 14 & 0.07 \\
9 & Industry & 14 & 0.20 \\
10 & Commercialization & 12 & 0.20 \\
11 & Spin off & 12 & 0.16 \\
12 & Scientist & 7 & 0.11 \\
13 & Life science & 7 & 0.23 \\
14 & Knowledge transfer & 7 & 0.02 \\
\hline
\end{tabular}

construction were the frontier hotspots of that period and belonged to the stage of rapid development. During the period from 2013 to 2017, the main research on academic entrepreneurship, such as entrepreneurial universities, academic entrepreneurship, and academic organizations, increased and began to pay attention to demand research such as entrepreneurial process and influencing factors. During 2018-2020, it is an empirical study of various research directions and international advanced experience, etc., which uses the methods of planned behavior theory, structural equation, and tie theory to analyze and find successful international models and methods to make up for their own defects. The future development direction will be to pay attention to the external environmental impact and find various problems in the specific academic entrepreneurial process through empirical research.

3.5.2. International Countries Frontier Analysis. 66 papers were analyzed by software, as shown in Figure 8. International studies during 2003-2010 were basic macrostudies, and the newly defined students' Entrepreneurship was in the stage of literature accumulation, involving entrepreneurship, company, knowledge, and knowledge transfer. (Wright, Mike, 2009) studied universities and business schools through the theory of system and resources and proposed to speed up the internal process construction of universities, such as knowledge transfer and university-industry connection [32]. From 2011 to 2016, international countries studies can organize and study the environmental impact in academic entrepreneurship such as patent, technology, economics, and productivity (Goethner, Maximilian) for the transformation of scientists in the process of academic entrepreneurship, through the analysis of technical behavior theory, it is found that the interaction between psychological factors and economic factors plays an important role in the transition of scholars' entrepreneurship [2]. During the period of 2017-2020, the mutant words are university technology transfer, start up, and behavior. 


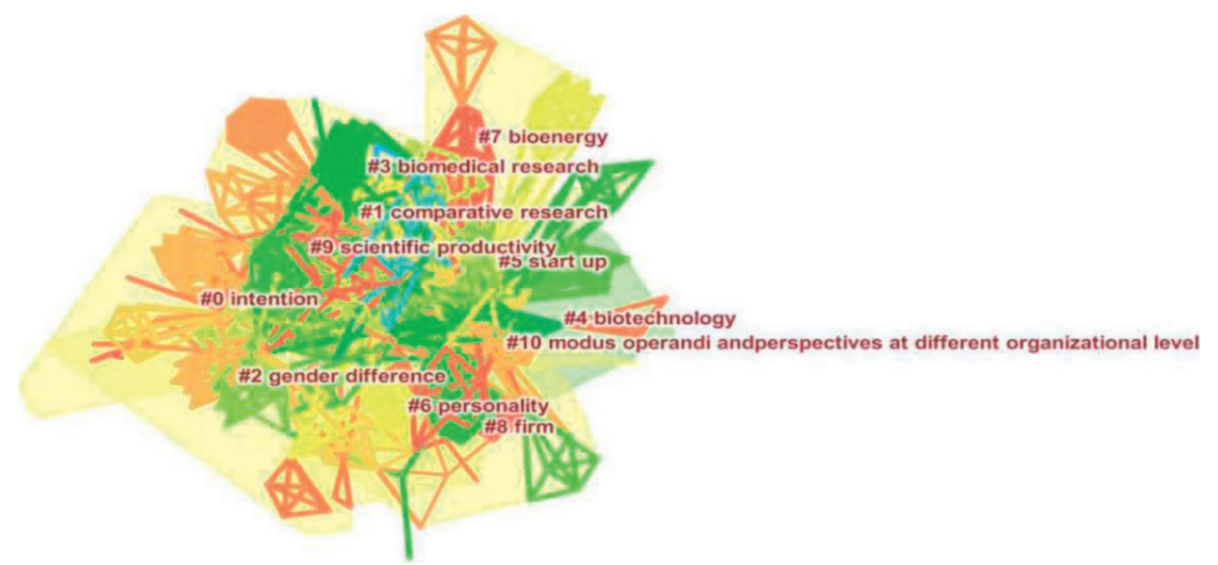

Figure 7: Keyword cluster map.

TABLe 11: Cluster member table.

\begin{tabular}{lccc}
\hline Category & Category name & Category members & $S$ \\
\hline 0 & Intention & value \\
1 & Comparative research & Intention; model; education & 0.849 \\
2 & Gender difference & Comparative research; journal; faculty & 0.756 \\
3 & Biomedical research & Gender difference; identification; experience & 0.778 \\
4 & Biotechnology & Biomedical research; commercialization; responsible innovation & 0.827 \\
5 & Start up & Biotechnology; strategy; uncertainty & 0.898 \\
6 & Personality & Start up; hub organization; boundary spanner & 0.802 \\
7 & Bioenergy & Personality; factor model; creation & 0.899 \\
8 & Firm & Bioenergy; science and technology policy; institutional theory & 0.875 \\
9 & Scientific Productivity & Firm; resource based view; bayh dole act & 0.864 \\
10 & Modus operandi and perspectives at & Modusoperandi and perspectives at different organizational level; scientific & 0.802 \\
& different organizational level & research organization; academic entrepreneurs and their national/local & 0.98 \\
\hline
\end{tabular}

Top 16 Keywords with the Strongest Citation Bursts

\begin{tabular}{|c|c|c|c|c|c|}
\hline Keywords & Year & Strength & Begin & End & $2003-2020$ \\
\hline enterpreneurship & 2003 & 1.6196 & 2003 & 2010 & - \\
\hline company & 2003 & 1.2449 & 2004 & 2009 & \\
\hline knowledge & 2003 & 1.2784 & 2004 & 2009 & \\
\hline network & 2003 & 1.292 & 2006 & 2011 & \\
\hline strategy & 2003 & 1.4903 & 2006 & 2011 & \\
\hline economics & 2003 & 1.1951 & 2009 & 2010 & \\
\hline research and development & 2003 & 1.5442 & 2011 & 2014 & \\
\hline experience & 2003 & 1.462 & 2012 & 2014 & \\
\hline productivity & 2003 & 1.7939 & 2013 & 2015 & \\
\hline patent & 2003 & 1.4196 & 2014 & 2016 & \\
\hline technology & 2003 & 1.4086 & 2014 & 2015 & \\
\hline university & 2003 & 1.1978 & 2015 & 2016 & \\
\hline bayh dole act & 2003 & 1.2263 & 2016 & 2018 & \\
\hline university technology transfer & 2003 & 1.786 & 2017 & 2018 & \\
\hline start up & 2003 & 1.8781 & 2018 & 2020 & \\
\hline behavior & 2003 & 1.396 & 2018 & 2020 & \\
\hline
\end{tabular}

Figure 8: International keyword mutation map.

Combined with literature analysis, we summarized the research frontier as a microlevel detailed study in the process of entrepreneurship (Civera, Alice) divided academic derivative companies into demand-oriented and opportunity-oriented, which linked academic entrepreneurship with the debate on opportunities and needs [33]. The frontier of research in China and international countries is summarized as the influence and promotion of various factors in the process of micro-level academic entrepreneurship. 


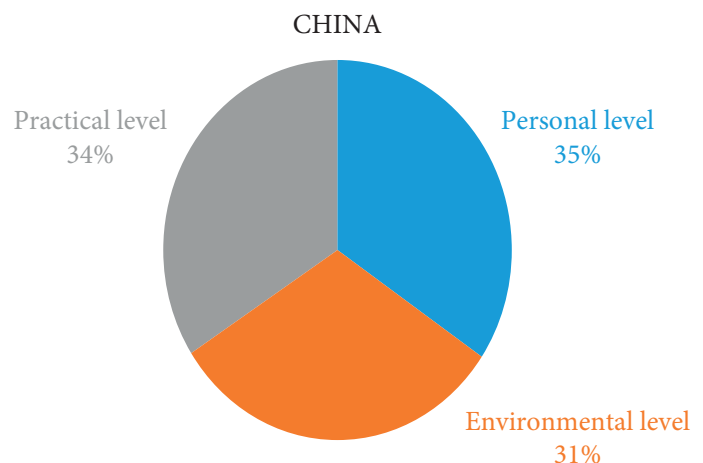

INTERNATIONAL COUNTRIES
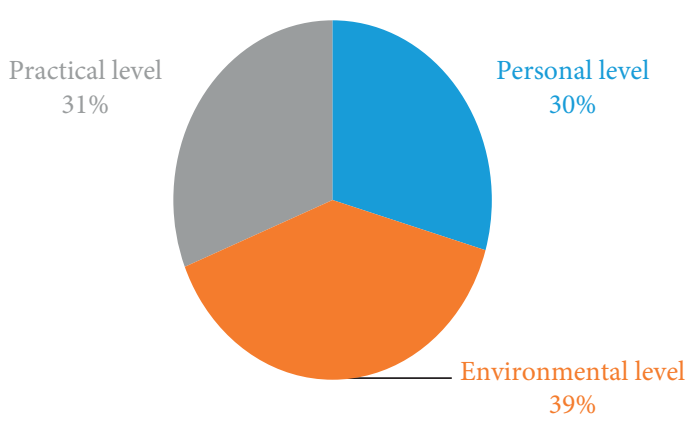

Figure 9: Research level view.

\subsection{Content Analysis}

3.6.1. Dimension View. Academic entrepreneurship research at home and abroad is divided into three aspects, the first environmental aspect, such as national policy, market business environment, research and development transfer, and cultural and social norms. Second personal aspects, such as entrepreneurial ability, gender, entrepreneurial experience, academic strength, and management ability $[10,31]$. Third, in terms of entrepreneurial practice, there will be many problems in a series of entrepreneurial processes of academic organizations and individuals, such as role conflict, operational mechanism, and entrepreneurial process analysis $[9,11]$.

As shown in Figure 9, through the research of 32 documents, it is found that the research on these three levels is basically the same, and the environmental level is relatively small, accounting for $31 \%$, and the personal level and practical level are 35\% and 34\%, respectively. In 66 international literature, environment accounts for 39\% at most, and individual and practice account for $30 \%$ and $31 \%$, respectively. Through the analysis of Chinese and international literature, it is found that the number of researches in the three aspects is basically similar, with more researches on individuals and practices in China and more researches on external factors such as environment, organization, and system in international countries.

3.6.2. Theories Involved. In the papers we write, we will quote other people's theories in the summary, as shown in Table 12. By counting the theories cited more than twice, the Chinese literature involves more entrepreneurship theory, triple helix theory, technology transfer, Schumpeter theory, grounded theory, etc. We can find that these basic theories are cited more, and the latter four methods are used less; international literature has been widely applied to entrepreneurship, system and resource theory, process theory, and entrepreneurial ecology theory. Comparing with Chinese theoretical application, it can be seen that Chinese researches tend to macrotheoretical research, while international researches tend to microentrepreneurial process researches.

3.6.3. Quantity of Published Articles in Periodicals. We counted 32 Chinese journals and 66international journals, as shown in Table 13, among which $50 \%$ were published in educational journals in China, 22\% in science and technology innovation, and $28 \%$ in other journals. Among them, there are 3 studies on education development, 3 studies on higher engineering education, and 2 journals on higher education exploration, etc. There are at most 11 papers published in international journals on technology transfer, 6 papers on research policy and 2-3 papers on management and economics. Through the comparison of periodicals, we find that Chinese research is biased towards education and puts forward policy suggestions, emphasizing the importance of academic entrepreneurship. Most international literature are empirical studies, which study the internal and external influencing factors and assistive agent obstacles in the process of academic entrepreneurship through model data analysis.

3.6.4. Methods. Papers need to use methods, as shown in Table 14. According to our statistics, $42 \%$ of Chinese literature found that case studies were used, 7 were theoretical studies through literature analysis, 3 were literature reviews, and other methods were not widely used. International literature tends to focus on empirical studies such as model application, actual case analysis, and descriptive statistics of data.

3.6.5. Types of Papers. As shown in Figure 10, through the statistics of 32 Chinese literature, it is found that $46 \%$ of the papers belong to theoretical research and $54 \%$ of the papers are research on various stages or internal and external influencing factors in the whole process of academic entrepreneurship. In 66 international literature, the theoretical research is obviously less than the empirical research, and the research differences in China and international countries can be seen from the research hotspots, journals, cocited literature, and methods.

3.6.6. Influencing Factors. Through our analysis of 32 Chinese and 66 international literature, it is found that there are three main factors affecting teachers' academic entrepreneurship, namely, human factors, platform factors, and environmental factors. According to statistics, the specific influencing factors are shown in Table 15. 
TABLE 12: Use theories table.

\begin{tabular}{|c|c|c|c|}
\hline Frequency & Chinese theory & Frequency & International theories \\
\hline 11 & Entrepreneurial theory & 18 & Entrepreneurial theory \\
\hline 4 & Schumpeter theory & 11 & Entrepreneurship spirit \\
\hline 4 & Triple helix theory & 5 & Knowledge transfer \\
\hline 4 & Paradox theory & 3 & Process theory \\
\hline 3 & Rooted theory & 3 & Theory of planned behavior \\
\hline 2 & Theory of planned behavior & 3 & Entrepreneurial ecosystem \\
\hline 2 & Knowledge spillover & 3 & Schumpeter theory \\
\hline
\end{tabular}

TABLE 13: Journal publication volume.

\begin{tabular}{|c|c|c|c|}
\hline Frequency & Chinese publications & Frequency & International publications \\
\hline 3 & Research on Educational Development & 11 & Journal of Technology Transfer \\
\hline 3 & Research in Higher Education of Engineering & 6 & Research Policy \\
\hline 2 & Higher Education Exploration & 3 & Science Technology and Society \\
\hline 2 & Higher Education in China & 3 & Technological Forecasting and Social Change \\
\hline 2 & Forum on Science and Technology in China & 2 & Academy of Management Perspectives \\
\hline 2 & College Education Management & 2 & Business Horizons \\
\hline 2 & Research and Development Management & 2 & European Economic Review \\
\hline 1 & Innovation Management & 2 & $\begin{array}{l}\text { International Entrepreneurship } \\
\text { and Management Journal }\end{array}$ \\
\hline
\end{tabular}

TAble 14: Method.

\begin{tabular}{|c|c|c|c|}
\hline Frequency & Chinese methods & Frequency & International methods \\
\hline 15 & (Multiple) case analysis & 20 & Regression model \\
\hline 7 & Literature analysis method & 14 & Case analysis \\
\hline 4 & Descriptive statistical analysis & 13 & Descriptive statistics \\
\hline 3 & Bibliometrics & 8 & Literature review \\
\hline 2 & Questionnaire analysis & 7 & Structural equation \\
\hline 2 & Grounded analysis & 2 & $4 \mathrm{~W} 1 \mathrm{H}$ \\
\hline 1 & Structural equation & 1 & Sample search field \\
\hline 1 & Regression analysis & & \\
\hline 1 & Coword analysis & & \\
\hline
\end{tabular}

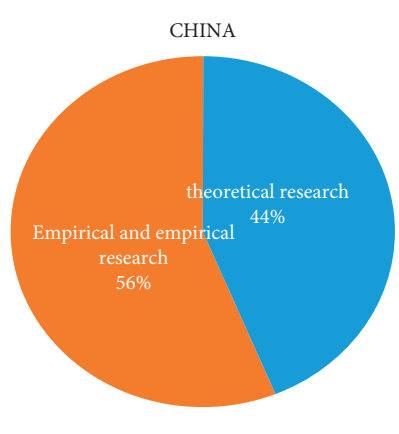

theoretical research

- Empirical and empirical research
INTERNATIONAL COUNTRIES

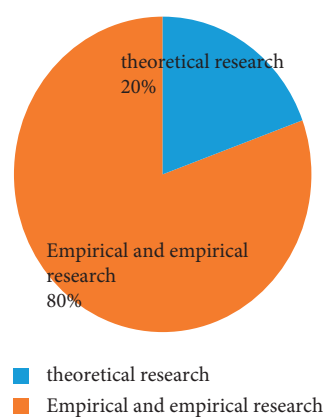

TABLE 15: Influencing factors.

\begin{tabular}{lc}
\hline & Risk management ability \\
Opportunity recognition ability & Academic professional knowledge \\
Personal factors & Entrepreneurship spirit \\
& Expected result \\
& Role conflict \\
& Mature technology transfer office \\
Organization factors & Perfect assessment mechanism \\
& Organization and cooperation \\
& Good reputation and resources \\
& Entrepreneurship education \\
Environmental factors & Entrepreneurship policy \\
& Regional economic structure \\
& Social network factors
\end{tabular}

FIGURE 10: Research category table. 


\section{Conclusions}

After literature analysis, the sample literature in China and international countries are divided into three categories: the first category is basic theoretical research, current situation, obstacles, and trends. The others are about the reference, enlightenment, and analysis of successful cases at home and abroad. Another part is a research article about the influencing factors of academic entrepreneurship. Among the 66 international literature, there are few literature reviews. Frank. T. Rothaermel made a comprehensive analysis of the early American and European research articles on academic entrepreneurship and summarized four research streams. Most of the literature researches are on the environmental factors such as system, resources, policies, and education in the process of academic entrepreneurship and the organizational influence of institutional universities.

(1) Just as we studied the literature distribution in Goal 1 , the literature on academic entrepreneurship is increasing day by day, the growth of Chinese literature is slightly policy-oriented, and international research is more active than Chinese research.

(2) The overall output of academic entrepreneurship literature has increased and its influence has become stronger. By studying the main authors, institutions, and national cooperation network Goal 2 in Chinese and international countries, we can find that academic entrepreneurship research is mature in North America and European countries such as the United States, Belgium, Germany, and Britain, and there is more cooperation among institutions; There are many cooperation groups between Chinese and international authors, and the academic entrepreneurial atmosphere needs to be further improved.

(3) The statistics of cocited documents in Goal 3 can help us find classic, core, and important documents in academic entrepreneurship documents, which represent an important context in this field. Among the cocited documents in China and international countries, Chinese cocited documents tend to be theoretical research at macrolevel, while international countries countries pay attention to the impact of microlevel individuals, institutions, and organizations on academic entrepreneurship and the research of academic entrepreneurship process through empirical research.

(4) Chinese and international studies have different emphasis and cultural differences. Therefore, through the analysis of the hot spots of Goal 4, we can find the places that can be used for reference, make up for the lack of research, and adjust the proposal of policy recommendations. Chinese hot spots focus on the macrolevel obstacles and impacts on academic entrepreneurship in colleges and universities; The difference between international literature and Chinese hot research lies in the empirical analysis of more microscopic factors in the process of academic entrepreneurship.
(5) Through analysis the research frontier, we found that Chinese and international research frontier is summarized as the promotion and hindrance of various factors at the micro level.

(6) Finally, the content analysis of Goal 6 can make up for what Citespace V software cannot do. Chinese literature is published in educational journals, and the theories used are entrepreneurship theory, root analysis, and paradox theory. The research types are mostly through bibliometric analysis and case analysis, with $46 \%$ theoretical research and 54\% empirical empirical research. There are many international literatures in terms of technology transfer, business, and economic environment, and the commonly used methods are Return model and descriptive statistics, which correspond to the commonly used theoretical system and resource theory. Among the literature types, $80 \%$ are empirical research and $20 \%$ are theoretical research.

Academic entrepreneurship has become an important channel to promote economic growth, and there are many factors affecting the development of academic entrepreneurship. By analyzing 98 Chinese and international literature, it is found that the research on academic entrepreneurship can be divided into three aspects: individual, environment, and organization. The research on influencing factors is also based on these three levels. Chinese research focuses on personal factors and organizational factors in entrepreneurial practice, while international research focuses on the environmental level, focusing on the influence of various factors in the entrepreneurial process. Academic entrepreneurship research needs to be further open and create a good atmosphere for academic entrepreneurship. This study gives personal suggestions from three aspects: individual, environment, and organization:

(1) Personally, academic entrepreneurs should balance their double identities as scholars and entrepreneurs, strengthen the cultivation of their own entrepreneurial ability, strengthen academic exchanges and create a good academic atmosphere.

(2) In terms of organizations (institutions and universities), actively build a platform related to academic entrepreneurship to give positive support to teachers' academic entrepreneurship, relax policies, and actively carry out entrepreneurship education.

(3) In terms of environment (national and regional), it is necessary to improve the supporting policies for academic entrepreneurship and give more favorable incentive policies.

At last, this study has some limitations in the retrieval and screening of sample data, and there may be a problem that the generality of the search terms is not high. The analysis method can be added with multisoftware and multianalysis methods such as BIBEXCEL and UCINET to make up for the deficiency of Citespace in analysis. 


\section{Data Availability}

The data used to support the findings of this study are included within the article in Section 2.1.

\section{Conflicts of Interest}

The authors declare that they have no conflicts of interest.

\section{Acknowledgments}

This paper was financially supported by the 100 Outstanding Innovative Talents Support Project of Hebei Province (SLRC2019005) and the Research and Practice Project of Higher Education Teaching Reform in Hebei Province (2019GJJG602) which made the present work possible.

\section{References}

[1] H. Li, "Academic organization and environment: a review of the research on academic entrepreneurship," Science, and science and technology management, vol. 30, no. 2, pp. 51-116, 2009.

[2] M. Goethner and M. Wyrwich, "Cross-faculty proximity and academic entrepreneurship: the role of business schools," The Journal of Technology Transfer, vol. 45, no. 4, pp. 1016-1062, 2020.

[3] Y. Huang, X. Zou, and P. Hou, "New trends in academic entrepreneurship research: concept, characteristics and factors," Research on Dialectics of Nature, vol. 29, no. 1, pp. 79-83, 2013.

[4] M. M. Crow, K. Whitman, and D. M. Anderson, "Rethinking academic entrepreneurship: university governance and the emergence of the academic enterprise," Public Administration Review, vol. 80, no. 3, pp. 11-515, 2020.

[5] R. E. N. Mei, "The empirical research on the relationship between university academic entrepreneurship and regional economic development from the perspective of coupling," College education management, vol. 13, no. 6, pp. 113-124, 2019.

[6] B. B. Fischer, P. R. Schaeffer, N. S. Vonortas, and S. Queiroz, "Quality comes first: university-industry collaboration as a source ofacademicentrepreneurship in a developing country," The Journal of Technology Transfer, vol. 43, no. 2, pp. 263-284, 2020.

[7] G. Yi, "The evolving process problems and countermeasures of academic entrepreneurship: based on the 1985-2016 university academic entrepreneurship policy text analysis," $R e$ search in Educational Development, vol. 37, no. 5, pp. 70-76, 2017.

[8] T. Yoshioka-Kobayashi and Tohru, "Institutional factors for academic entrepreneurship in publicly owned universities in Japan: transition from a conservative anti-industry university collaboration culture to a leading entrepreneurial university," Science Technology \& Society, vol. 24, no. 3, pp. 423-445, 2019.

[9] M. Abreu and V. Grinevich, "Gender patterns in academic entrepreneurship," The Journal of Technology Transfer, vol. 42, no. 4, pp. 763-794, 2017.

[10] Y. Zhang, "The evaluation and improvement path of academic entrepreneurship ability of entrepreneurship education teachers in colleges and universities," College education management, vol. 12, no. 2, pp. 80-87, 2018.
[11] D. Qi, Q. Mai, and Q. Liao, "Research on academic entrepreneurship creation process based on grounded theory," Science Research, vol. 35, no. 8, pp. 1212-1252, 2017.

[12] Y. Su and W. Zhao, "The empirical research on the influence factors of teachers' academic entrepreneurship in research universities: based on the theory of planned behavior," Research in Educational Development, vol. 39, no. 1, pp. 70-84, 2019.

[13] Y. Su and W. Zhao, "Research on influence factors model of teachers' academic entrepreneurship in research universitiesan exploratory research based on grounded theory," China's Higher Education Research, vol. 9, pp. 36-42, 2017.

[14] A. Gt, B. Mb, and C. Rm, "What can we learn from the JATM literature for the future of aviation post Covid19? - a bibliometric and visualization analysis," Journal of Air Transport Management, vol. 89, pp. 1-15, 2020.

[15] X. Chen and Y. Liu, "Visualization analysis of high-speed railway research based on Citespace," Transport Policy, vol. 85, pp. 1-17, 2020.

[16] Sheikhnejad and Yigitcanlar, "Scientific landscape of sustainable urban and rural areas research: a systematic scientometric analysis," Sustainability, vol. 12, no. 4, pp. 1-28, 2020.

[17] L. Huang, K. Chen, and M. Zhou, "Climate change and carbon sink: a bibliometric analysis," Environmental Science and Pollution Research, vol. 27, no. 8, pp. 8740-8758, 2020.

[18] Y. Chen, C. Chen, Z. Liu, Z. Hu, and XianwenWang, "The methodology function of Cite Space mapping knowledge domains," Science Research, vol. 33, no. 2, pp. 242-253, 2015.

[19] R. Grimaldi, M. Kenney, D. S. Siegel, and M. Wright, "30 years after Bayh-Dole: reassessing academic entrepreneurship," Research Policy, vol. 40, no. 8, pp. 1045-1057, 2011.

[20] M. Abreu and V. Grinevich, "The nature of academic entrepreneurship in the UK: widening the focus on entrepreneurial activities," Research Policy, vol. 42, no. 2, pp. 408-422, 2013.

[21] J. Bercovitz and M. Feldman, "Academic entrepreneurs: organizational change at the individual level," Organization Science, vol. 19, no. 1, pp. 69-89, 2008.

[22] T. E. Stuart and W. W. Ding, "When do scientists become entrepreneurs? The social structural antecedents of commercial activity in the academic life sciences," American Journal of Sociology, vol. 112, no. 1, pp. 97-144, 2006.

[23] P. D'Este and M. Perkmann, "Why do academics engage with industry? the entrepreneurial university and individual motivations," Social Science Electronic Publishing, vol. 36, no. 3, pp. 316-339, 2011.

[24] P. Markus, T. Valentina, McKelvey, and Maureen, "Academic engagement and commercialisation: a review of the literature on university-industry relations," Research Policy, vol. 42, no. 2, pp. 423-442, 2013.

[25] C. Haeussler and J. A. Colyvas, "Breaking the ivory tower: academic entrepreneurship in the life sciences in UK and Germany," Research Policy, vol. 40, no. 2, pp. 41-54, 2011.

[26] F. T. Rothaermel, S. D. Agung, and L. Jiang, "University entrepreneurship: a taxonomy of the literature," Industrial and Corporate Change, vol. 16, no. 4, pp. 691-791, 2007.

[27] Z. Yin and R. Li, "Academic entrepreneurship of faculty in American research universities and its enlightenments," $E d$ ucational Sciences, vol. 34, no. 3, pp. 88-94, 2018.

[28] H. Li, "Correspondence between indirect academic entrepreneurship and entrepreneurship education at university: a case from babson college," Science and Technology Management, vol. 37, no. 1, pp. 108-114, 2016.

[29] R. Pierluigi and S. Giustina, "Digital academic entrepreneurship: the potential of digital technologies on academic 
entrepreneurship," Technological Forecasting and Social Change, vol. 146, pp. 900-911, 2019.

[30] J. Gosens, H. Hellsmark, T. Kåberger et al., "The limits of academic entrepreneurship: conflicting expectations about commercialization and innovation in China's nascent sector for advanced bio-energy technologies," Energy Research \& Social Science, vol. 37, pp. 1-11, 2018.

[31] K. Barbara, "The role of creativity in the context ofacademicentrepreneurship," Creativity and Innovation Management, vol. 29, no. 2, pp. 254-267, 2020.

[32] M. Wright, E. Piva, S. Mosey, and A. Lockett, "Academic entrepreneurship and business schools," The Journal of Technology Transfer, vol. 34, no. 6, pp. 560-587, 2009.

[33] A. Civera, M. Meoli, and S. Vismara, "Engagement of academics in university technology transfer: opportunity and necessity academic entrepreneurship," European Economic Review, vol. 123, p. 10336, 2020. 